\title{
Non-native fish species in heated lakes: Origins and present status
}

\author{
Andrzej Kapusta, Elżbieta Bogacka-Kapusta
}

Received - 15 March 2015/Accepted - 29 April 2015. Published online: 30 June 2015; Inland Fisheries Institute in Olsztyn, Poland Citation: Kapusta A., Bogacka-Kapusta E. 2015 - Non-native fish species in heated lakes: Origins and present status - Arch. Pol. Fish. 23: 121-129.

\begin{abstract}
This paper discusses the problem of the occurrence of non-native fish species in a strongly transformed aquatic ecosystem. The changes in this ecosystem are caused by warm water discharges from two electric power plants. Twelve non-native fish species are confirmed to occur in the system of five heated lakes located in central Poland. In total, 30\% of the total number of non-native species confirmed in Polish inland waters were noted. Aquaculture and fisheries are the primary sources of non-native species in these lakes. Among the species identified, most reached the lakes or canals by escaping from farming facilities or through commercial stocking. Four species have established stable populations. Pseudorasbora parva (Temminck \& Schlegel), Carassius gibelio (Bloch), and Carassius auratus (L.) are invasive species that occur abundantly in all the lakes, while Cyprinus carpio L. reproduces irregularly and only in the most heated lakes. The remaining species do not reproduce in the heated lakes system, or anywhere else in Poland; still, the threat these species pose must not be underestimated.
\end{abstract}

Keywords: aquaculture, fisheries, introduction, invasion, pathways

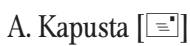

Department of Hydrobiology

Inland Fisheries Institute in Olsztyn

ul. Oczapowskiego 10, 10-719 Olsztyn, Poland

Tel: +48 895241039; e-mail: kasta@infish.com.pl

E. Bogacka-Kapusta

Department of Ichtyology

Inland Fisheries Institute in Olsztyn, Poland
}

\section{Introduction}

Invasions of non-native species are considered to pose serious threats to inland water ecosystems (Dudgeon et al. 2006). The ecological consequences of freshwater fish invasions became a significant problem at the end of the twentieth century when this process was perceived to be a significant element of changes occurring in the environment, sometimes on a global scale. Invasive, non-native species negatively impact a range of animal and plant taxa in many lakes and rivers in the world, which is why they are considered to be one of the toughest problems facing contemporary environmental conservation (Cucherousset and Olden 2011). Fish introductions have a long history globally (Gozlan et al. 2010a). The spread of non-native species is often a consequence of people moving them either intentionally or unintentionally. Despite certain advantages, the culture of exotic aquatic organisms poses a threat to local fish populations. Non-native species can dominate new habitats and cause irreversible changes in the environments of inland waters.

Formerly, some fish species in Poland were imported and introduced into the natural environment consciously and purposefully, such as the peled, Coregonus peled Gmelin, while others were imported for aquaculture, such as the grass carp, Ctenopharyngodon idella (Val.) or as ornamental

\footnotetext{
C Copyright by Stanisław Sakowicz Inland Fisheries Institute in Olsztyn.

(c) 2015 Author(s). This is an open access article licensed under the Creative Commons Attribution-NonCommercial-NoDerivs License (http://creativecommons.org/licenses/by-nc-nd/3.0/).
} 
fish, such as the sunfish, Lepomis gibbosus (L.) (Grabowska et al. 2010). Some of these fish escaped from fish farms and created stable populations (Witkowski and Grabowska 2012). Many other fish species were introduced accidentally through different pathways. Regardless of how they arrived, non-native species in natural ecosystems has become one of the most serious problems facing the management of the natural environment.

In addition to changes in the habitat conditions of native species, inland water thermal pollution can facilitate invasions and adaptations of non-native species. Unique thermal, trophic, and hydrological conditions prevail in the lake complex near Konin, which is heated by waters from local power plants. Lakes with heated waters are also examples of how freshwater ecosystems function when affected by climate change. Studies performed to date indicate that the ecological structure of these ecosystems also depends on the development of the aquatic biocenosis, and especially on the expansion of non-native species of plants and animals (Kraszewski and Zdanowski 2007, Sinicyna and Zdanowski 2007, Ejsmont-Karabin 2011). Increased water temperature caused by climate change can change the effectiveness of abiotic filters and render the influx of non-native species easier (Rahel and Olden 2008). This paper describes the problem of non-native fish species in a strongly transformed aquatic ecosystem. The paper discusses the reasons for introducing the non-native species and the current status of these fishes.

\section{Study area}

The study area was the system of five-lakes located in the Oder River drainage basin in the Wielkopolsko-Kujawskie Lakeland. The total lake surface area is $13 \mathrm{~km}^{2}$, and the length of the canals is $26 \mathrm{~km}$. All of the lakes are part of the open cooling system of two power plants. The first power plant began to heat lakes Pątnowskie and Licheńskie and the southern part of Lake Mikorzyńskie in 1958. The current system to cool discharged waters was expanded in the late 1960s, and in 1970 the second power plant, which is located on Lake Gosławskie, was launched. This is how canals came to link the five lakes, and from 1970 lakes Gosławskie and Ślesińskie and the northern part of Lake Mikorzyńskie were heated. The heated water discharged from the power plants caused significant increases in mean water temperature in the lakes. The degree to which the water was heated in the each of the lakes differed (Stawecki et al. 2013). In the warmest lakes (Licheńskie, Gosławskie, Pątnowskie), the water did not freeze in winter, and in summer temperatures in the littoral zone reach $30-32^{\circ} \mathrm{C}$. The artificial canal system linking the lakes was also connected to fish ponds, Lake Gopło, and the large lowland Warta River. During the study period, commercial fisheries management was conducted in all of the lakes, while in the canals and fish ponds cyprinids, predatory fish, and sturgeons were being farmed. Initially, the cyprinids were farmed in earthen ponds, but in the last twenty years cyprinid cages aquaculture in canals has been growing.

\section{Materials and methods}

Information on the occurrence of non-native species in the heated lakes comes from research catches conducted in the period from 1966 to 2013 (Zawisza and Backiel 1972, Wilkońska and Żuromska 1977a, Wilkońska 1994, Tereschenko et al. 2007, A. Kapusta unpublished data). Catches of small fishes in the littoral zones of lakes Licheńskie, Gosławskie, and Ślesińskie are performed at least twice annually, while fish are caught less frequently in lakes Pątnowskie and Mikorzyńskie and the canals linking the lakes. Data from commercial catches in all five lakes were also used (Ciepielewski 2000, 2001, A. Kapusta unpublished data). 


\section{Results and discussion}

\section{Taxonomic composition and origin of species}

The occurrence of 12 non-native fish species was confirmed in the heated lake system (Table 1). Najberek and Solorz (2011) mention nine non-native fish species in these lakes in the monograph on non-native fauna in Poland. Their list did not include sturgeons or rainbow trout, Oncorhynchus mykiss (Walbaum), but it did include Ictiobus niger Rafinesque, which has, in fact, never occurred in the heated Konin lakes. In their description of this species, Szumiec and Ronchetti (1987) propose that I. niger could supplement aquaculture in ponds and lakes with higher water temperatures, including the Konin lakes. Subsequently, a monograph on freshwater fishes of Poland
(Brylińska 2000), citing the publication above, reported that $I$. niger was supposed to supplement the ichthyofauna of heated lakes. Najberek and Solorz (2011) were probably misled by these data and hastily included I. niger among the species that had been introduced to the heated Konin lakes.

The non-native fish species confirmed to occur in the heated lake system comprise $30 \%$ of the total number of non-native species known to occur in Polish inland waters. In the past 800 years about 40 fish species have been introduced to Polish waters (Grabowska et al. 2010, Kapusta 2011). The motives for introducing non-native species to heated waters differed slightly from those in other parts of Poland. The main introduction pathway of non-native fish species into the heated lakes was aquaculture and fisheries. While in other inland Polish waters the primary motivation was for fish culture, followed by sport fishing, ornamental purpose, biomanipulation, and

Table 1

Non-native fish species in the heated lakes, date of detection, geographic origin, reason for introduction, mechanism of spread, and species status

\begin{tabular}{|c|c|c|c|c|c|}
\hline Species & $\begin{array}{l}\text { First } \\
\text { report }\end{array}$ & $\begin{array}{l}\text { Original } \\
\text { area }\end{array}$ & Reason & $\begin{array}{l}\text { Mechanism } \\
\text { of introduction }\end{array}$ & $\begin{array}{l}\text { Present } \\
\text { status }\end{array}$ \\
\hline Acipenser ruthenus L. & $2009^{*}$ & $\begin{array}{l}\text { Siberia, Black, Azov } \\
\text { and Caspian Seas }\end{array}$ & Aquaculture & Escaped fish farming & Artificial reproduction \\
\hline Acipenser baerii Brandt & $2009 *$ & Asia & Aquaculture & Escaped fish farming & Artificial reproduction \\
\hline $\begin{array}{l}\text { Acipenser gueldenstaedtii } \\
\text { Brandt \& Ratzeburg }\end{array}$ & $2009 *$ & $\begin{array}{l}\text { Black, Azov and } \\
\text { Caspian Seas }\end{array}$ & Aquaculture & Escaped fish farming & Artificial reproduction \\
\hline Carassius auratus (L.) & $2004^{*}$ & Asia & Ornamental & Escaped fish farming & $\begin{array}{l}\text { Natural reproduction, } \\
\text { invasive }\end{array}$ \\
\hline Carassius gibelio (Bloch) & $1966^{*}$ & Asia & Fisheries, angling & Stocking programs & $\begin{array}{l}\text { Natural reproduction, } \\
\text { invasive }\end{array}$ \\
\hline Ctenopharyngodon idella (Val.) & 1966 & Far East & Fisheries, angling & Stocking programs & Artificial reproduction \\
\hline Cyprinus carpio L. & $1966^{*}$ & $\begin{array}{l}\text { Black, Caspian and } \\
\text { Aral Seas }\end{array}$ & Fisheries, angling & Stocking programs & Natural reproduction \\
\hline $\begin{array}{l}\text { Hypophthalmichthys molitrix } \\
\text { (Val.) }\end{array}$ & 1967 & Far East & Fisheries & Stocking programs & Artificial reproduction \\
\hline $\begin{array}{l}\text { Hypophthalmichthys nobilis } \\
\text { (Richardson) }\end{array}$ & 1984 & Far East & Fisheries & Stocking programs & Artificial reproduction \\
\hline $\begin{array}{l}\text { Oncorhynchus mykiss } \\
\text { (Walbaum) }\end{array}$ & $2004^{*}$ & North America & Aquaculture & Escaped fish farming & Artificial reproduction \\
\hline Oreochromis niloticus (L.) & 2002 & Africa & Aquaculture & Escaped fish farming & Extinct \\
\hline $\begin{array}{l}\text { Pseudorasbora parva } \\
\text { (Temminck \& Schlegel) }\end{array}$ & 2002 & Far East & Aquaculture & $\begin{array}{l}\text { Introduced } \\
\text { accidentally }\end{array}$ & $\begin{array}{l}\text { Natural reproduction, } \\
\text { invasive }\end{array}$ \\
\hline
\end{tabular}

*date of first confirmation of occurrence in lakes, could have occurred earlier 
anthropogenic expansion by linking various drainage basins with canals (Witkowski and Grabowska 2012). Among the species confirmed, the most fish were introduced into the lakes or canals by escapees from farms and also from commercial stocking (Table 1).

In the inland waters of Poland 11 non-native species have established their own stable populations (Grabowska and Przybylski 2015). As much as $36 \%$ of these species occur in the heated lake system, because four species have established stable populations. P. parva, C. gibelio, and C. auratus are invasive species that occur in large numbers in all of the lakes. However, C. carpio L., reproduces irregularly and then only in the warmest of the lakes (Kapusta 2004). The other species do not reproduce in the heated lake system, or anywhere else in Poland (Witkowski and Grabowska 2012).

\section{Case studies}

\section{Topmouth gudgeon}

In Poland $P$. parva inhabits more than 50 sites mostly in pond complexes or in the vicinity of them (Witkowski 2009). The spread of this species is facilitated by stocking ponds, lakes, and rivers with stocking material that includes $P$. parva. Adult specimens of this species were confirmed to occur in the heated lakes in 2002 (Kapusta 2004, Kapusta et al. 2008), and it is likely that they reached them from nearby carp ponds. In following years increased abundance and the colonization of subsequent lakes were confirmed. The spread of the species was probably facilitated by the system of canals that linked the lakes. In the first years of its occurrence, $P$. parva inhabited Lake Licheńskie, and in the 2004-2005 period it spread to lakes Pątnowskie and Mikorzyńskie through the system of canals (Fig. 1). Located at the edge of the cooling system, the waters of Lake Gosławskie were inhabited last (Kapusta et al. 2014). P. parva prefers the shallow littoral zone $(<1.0 \mathrm{~m})$ overgrown with macrophytes. It occurs most abundantly in the littoral zones overgrown with the exotic species Vallisneria spiralis L. Spawning in the warmest lakes occurred in the shallow littoral from April to September at water temperatures ranging from 15 to $30^{\circ} \mathrm{C}$. Eggs was deposited, most frequently on aquatic vegetation, in several batches. The smallest mature female from Lake Licheńskie was just $18.9 \mathrm{~mm}$ in standard length (SL), although the mean size at maturity within the population was 33.93 mm SL (Záhorská et al. 2013). The P. parva population occurring in Lake Licheńskie was characterized by a high degree of flexibility in its life history, which was evident in the substantial variability in its reproductive parameters (Záhorská et al. 2014). The high phenotype plasticity of the life history of $P$. parva permitted it to effectively inhabit very different habitats (Gozlan et al. 2010b), even such variable environment as that of the heated Lake Licheńskie (Záhorská et al. 2014).

The impact of $P$. parva on the local fish population is significant. Decreases in the abundance and richness of autochthonous species were confirmed as a result of predation, food competition, spawning disruptions, and spawning ground destruction (Gozlan et al. 2010b, Jackson and Britton 2013). As the abundance of the $P$. parva population increased in the heated lakes, changes were noted in the structures of small-sized fish assemblages inhabiting the shallow littoral zones (Kapusta et al. 2006). Particularly drastic reductions in abundance were noted in common bleak, Alburnus alburnus (L.) and tench, Tinca tinca (L.).

\section{Chinese carps}

Chinese cyprinids were imported to Poland in 1964-1965 (Witkowski and Grabowska 2012). The heated lakes were first stocked with C. idella in 1966, followed by Hypophthalmichthys molitrix (Val.) the next year (Ciepielewski 2000). The lakes were stocked with Hypophthalmichthys nobilis (Richardson) in 1984, but it is likely that a certain amount of this species was released earlier along with $H$. molitrix. In subsequent years, the heated lakes were stocked with varying frequencies and quantities. Chinese cyprinids with mean body weights ranging from 

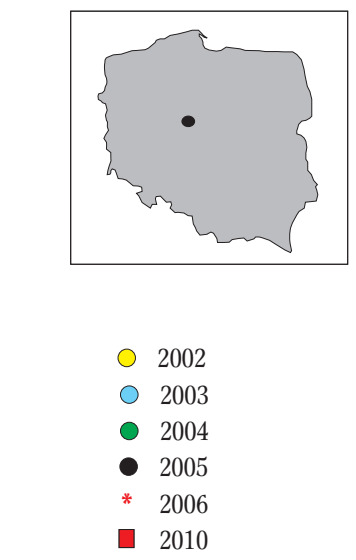

002

2003

2004

2006

2010

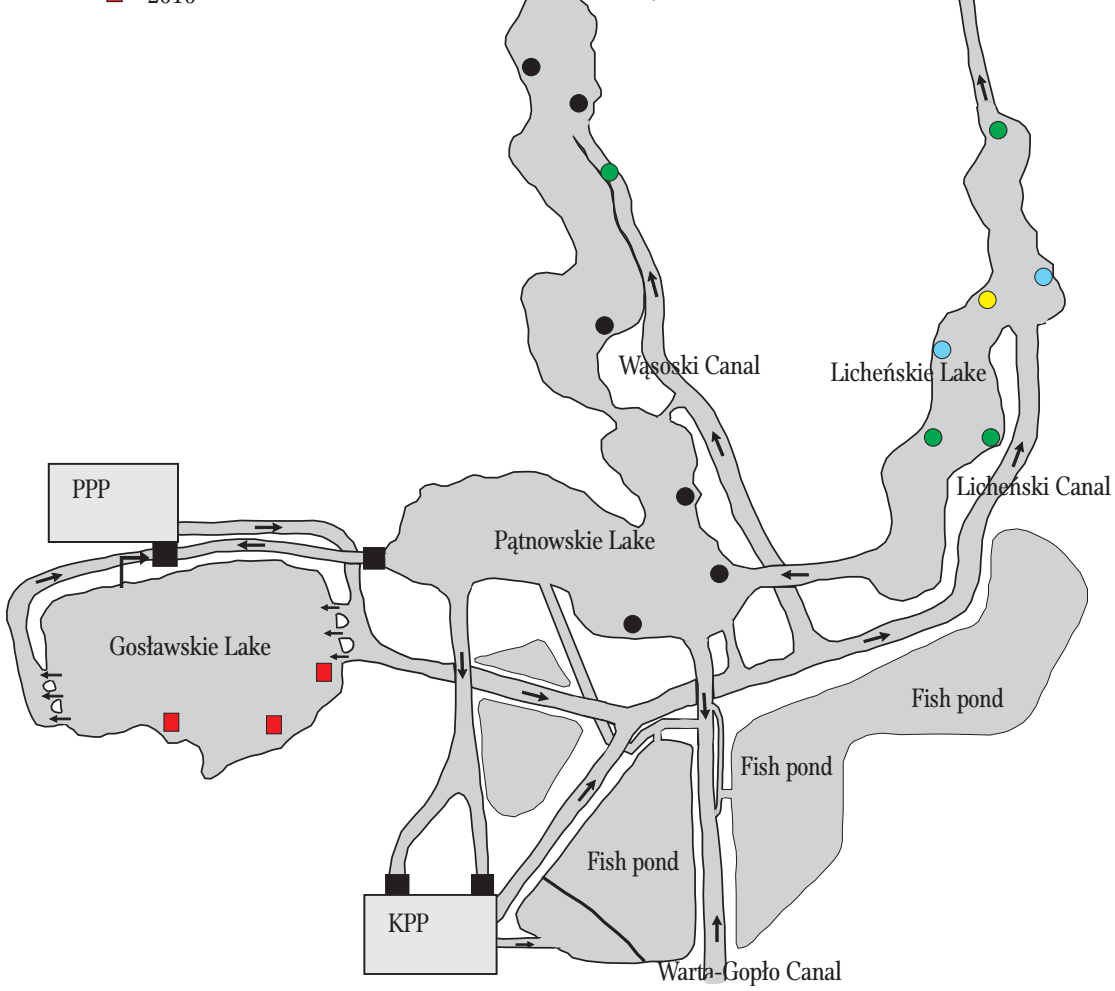

Figure 1. Records of P. parva in the heated lakes system. Small map: location of the heated lakes in Poland.

200 to $500 \mathrm{~g}$ were released mainly into lakes Gosławskie and Licheńskie. The stocking was performed for commercial aims, and the effect of them was intended to be larger commercial catches. Over time, it appeared that the effectiveness of catching these fish was very low. Larger quantities were caught once over dozen years when Chinese cyprinids were caught at a yield of 90-100 $\mathrm{kg} \mathrm{ha}^{-1}$. The introduction of Chinese cyprinids caused changes in the native fish species structure and decreased catches of autochthonous fish species. Overall decreases in commercial catches were noted in the lakes that had been stocked with Chinese cyprinids. The initial dominant in the catches, common bream, Abramis brama (L.), was replaced by roach, Rutilus rutilus (L.) (Ciepielewski 2001). Intense stocking with Chinese cyprinids negatively impacted the native fishes. Stocking the lakes with C. idella changed spawning conditions for phytophilous fish. Several months after releasing $C$. idella into the lakes, they 
had consumed nearly all the aquatic vegetation (Wilkońska and Żuromska 1977b, Wilkońska 1988a). The impact of silver carp and bighead carp was less drastic, but it was also negative. During periods of intense stocking with these species, decreases in the abundance of larval and juvenile stages of native fish species were noted, with the greatest noted among roach, rudd, Scardinius erythrophthalmus (L.), crucian carp, Carassius carassius (L.), Prussian carp, and carp (Wilkońska 1988b).

\section{Tilapia}

The occurrence of Oreochromis niloticus (L.) was noted in the 1990s in heated waters of western and southern Poland, and it was caught by recreational fishers in the Rybnik Reservoir (Witkowski 2011). O. niloticus was noted in the heated discharge waters of the Konin and Pątnów power plants only in the Licheńskie Canal and in Lake Licheńskie in 2002-2003. In spring 2002, adult specimens, which had escaped from cages in the discharge canal, were observed in the canal and lake. Tilapia were caught in large numbers by recreational fishers. Specimens in Lake Licheńskie were noted to be in spawning color which indicated reproductive behavior. In the next year, one juvenile specimen measuring $35 \mathrm{~mm}$ in length with a body weight of $1.8 \mathrm{~g}$ (Fig. 2) was caught on August 19, 2003 in the littoral zone of Lake Licheńskie. In subsequent years, O. niloticus was not noted in the heated canal and lake system. During this period, canal cages of this species ceased.

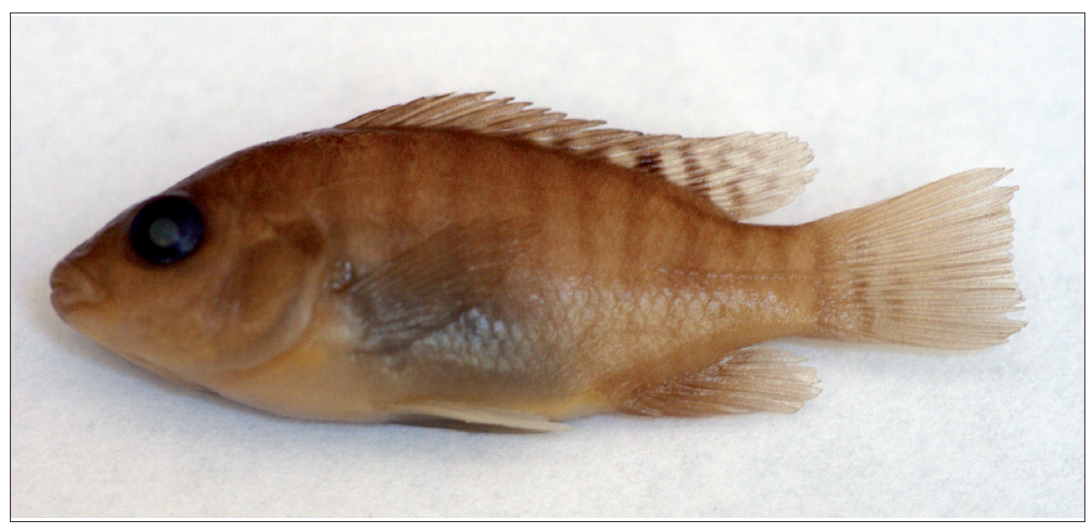

Figure 2. Juvenile O. niloticus captured in Lake Licheńskie. Photograph by A. Kapusta.
A limiting factor for this fish, even in the most intensely heated Lake Licheńskie, was probably water temperature. A similar situation occurred in the Rybnik Reservoir, where tilapia disappeared when the water was heated to a lesser degree.

\section{Carps}

C. carpio was the first species to be introduced to Polish waters (Grabowska et al. 2010, Witkowski and Grabowska 2012). The precise date when the heated lakes were stocked with carp is not known. In 1966-1967, natural carp spawning was observed in Lake Licheńskie, the most heated of the lakes (Wilkońska and Żuromska 1977b). Stocking this lake with grass carp led to the near total disappearance of submerged vegetation and the destruction of carp spawning grounds (Wilkońska and Żuromska 1977a). Later, along with decreasing numbers of grass carp in the lake, the littoral began to regenerate naturally; consequently, carp began to spawn in Lake Licheńskie (Wilkońska 1994). The decreased degree of heating in the lake in the early twenty-first century (Stawecki et al. 2013) could have been the cause of irregular carp spawning in late June and early July (Kapusta 2004). Increased water temperature in Lake Gosławskie from power plant water discharge caused changes in fish reproduction. Carp spawning in Lake Gosławskie was noted for the first time in 1971. From this time, carp occur in Lake Gosławskie in small quantities, and spawning occurs irregularly (Wilkońska 1994, A. Kapusta unpublished data).

The systematics and origin of the genus Carassius remains a taxonomic challenge (Rylková et al. 2013). Non-native fish species of the genus Carassius are represented in Poland by at least two species: $C$. auratus and $C$. gibelio (Kotusz 2011). The occurrence of both species was noted in the heated lake system (Table 1). The colonization of the lakes by these species if difficult to describe, because for many 
years researchers investigating the fishes of the heated lakes identified them as C. auratus gibelio (Wilkońska and Żuromska 1977a, Wilkońska 1994). These fish probably belonged to the species $C$. gibelio. From 1966 to 1992, specimens of this species were confirmed in lakes Gosławskie and Licheńskie, while they did not occur in Lake Ślesińskie. In 2001, C. gibelio was noted in Lake Ślesińskie. It certainly occurred in this lake previously, but it was not detected in this lake because of infrequency of monitoring catches. C. gibelio spawned in Lake Licheńskie from May to July and occurred abundantly in habitats with abundant growth of $V$. spiralis (Kapusta 2004). Specimens with the coloring of $C$. auratus appeared in the canals and the warmest lakes along with the development of ornamental fish farms supplied by heated waters. Monitoring catches of fish in July 2005 indicated the abundant occurrence of $C$. auratus in the Licheńskie and Wąsowskie canals and in lakes Licheńskie, Pątnowskie, and Mikorzyńskie (A. Kapusta - unpublished data).

\section{Conclusions}

The heated lakes of the Konin area are considered to be hot spot of invasions of non-native aquatic organisms (Najberek and Solarz 2011). The abundant occurrence of non-native species of animals and plants is evidence of how rapid, wide-ranging changes in the biocenosis can be effected by relaxing environmental conditions through heating water. Among the twelve non-native fish species noted in these lakes, the dominant ones were either introduced intentionally or they are escapees from aquaculture. This situation could have been predicted since aquaculture is the main pathway of non-native fish species introduction throughout the world (Gozlan et al. 2010a) and in Poland (Witkowski and Grabowska 2012). In the initial period of heating the lakes with discharged waters, the prevailing thinking was that the altered thermal conditions would create great opportunities for the fisheries (Opuszyński and Bieniarz 1974).
Chinese carps were introduced intentionally into the lakes, where these fish found advantageous conditions as is reflected in their rapid growth rates (Ciepielewski 2001). That the non-native species could or would negatively impact the native fish species was not expected. The particularly drastic changes in the abundance of native phytophilous species was linked to grass carp consuming aquatic vegetation (Wilkońska and Żuromska 1977a). A second group of non-native fish species comprised escapees from aquaculture. The heated waters discharged through the canals to the lakes are used by three fish farms that rear fish in cages in the canals or in fish ponds supplied with the heated water from these canals. The occurrence of sturgeons, rainbow trout, tilapia, and goldfish were linked to either unintentional or intentional introductions. While most of these species are incapable of breeding in the heated lakes, the threat they pose should not be underestimated. Many non-native helminth parasite species have been noted in the introduced species (Witkowski and Grabowska 2012).

Non-native fish species pose a range of threats to local ecosystems and human well-being. Limiting the impact non-native species have on the aquatic biocenosis is usually very difficult and expensive (Gozlan et al. 2010a). When considering the significance of introducing non-native species, one should take into consideration their overall economic value with local levels of ecological risk. Among the non-native fish species confirmed in the heated lakes were some with invasive status in Poland (Grabowska et al. 2010) as well as others which, in their natural area of occurrence, are threatened with extinction to different degrees, such as sturgeon (Pikitch et al. 2005). Local dependencies among native and non-native species are not permanently negative (Guo and Olden 2014). Sometimes some non-native species are perceived as not harmful, and even desirable (Schlaepfer et al. 2011). Despite everything, it is difficult to find any positive aspects of the introduction of non-native species to the heated lakes of central Poland. Even in the case of sturgeon the risk exists of them moving from the lakes into the Warta River, which is very important to the 
restoration of Acipenser oxyrinchus Mitchill in Poland (Gessner et al. 2006, Kolman et al. 2011). Non-native sturgeon species pose a substantial threat to the success of restoring $A$. oxyrinchus to open waters because, among other things, they can carry parasites and compete for food resources. This is why the exploitation of the heated waters by fisheries and aquaculture should be more sustainable, and how introduced species impact local fish species should be monitored.

Acknowledgments. The study was conducted within the framework of the statutory research program of the Inland Fisheries Institute in Olsztyn (No. S009).

Author contributions. A.K. designed the research; A.K and E.B.K. performed the research, and wrote the paper.

\section{References}

Brylińska M. 2000 - Freshwater fishes of Poland Wydawnictwo Naukowe PWN, Warszawa: 338-339 (in Polish).

Ciepielewski W. 2000 - Commercial catches. Biomass of several fish species in two heated Konin lakes stocked with grass and silver carp - Komun. Ryb. 5: 11-17 (in Polish).

Ciepielewski W. 2001 - Herbivorous fish in two of the most intensely heated lakes in the Konin complex - Komun. Ryb. 5: 11-17 (in Polish).

Cucherousset J., Olden J.D. 2011 - Ecological impacts of non-native freshwater fishes - Fisheries 36: 215-230.

Dudgeon D., Arthington A.H., Gessner M.O., Kawabata Z.I., Knowler D.J., Lévęque C., Naiman R.J., Prieur-Richard A.H., Soto D., Stiassny M.L.J., Sullivan C.A 2006 Freshwater biodiversity: importance, threats, status and conservation challenges - Biological Reviews of the Cambridge Philosophical Society, 81: 163-182.

Ejsmont-Karabin J. 2011 - Does invasion of Vallisneria spiralis L. promote appearance of rare and new rotifer (Rotifera) species in littoral of the lakes heated by power station (Konin lakes, W. Poland)? - Pol. J. Ecol. 59: 201-207.

Gessner J., Arndt G.M., Tiedemann R., Bartel R., Kirschbaum F. 2006 - Remediation measures for the Baltic sturgeon: status review and perspectives - J. Appl. Ichthyol. 22 (Suppl. 1): 23-31.
Gozlan R.E., Britton J.R., Cowx I., Copp G.H. 2010a - Current knowledge on non - native freshwater fish introductions J. Fish Biol. 76: 751-786.

Gozlan R.E., Andreou D., Asaeda T., Beyer K., Bouhadad R., Burnard D., Caiola N., Cakic P., Djikanovic V., Esmaeili H.R., Falka I., Golicher D., Harka A., Jeney G., Kováč V., Musil J., Nocita A., Povz M., Poulet N., Virbickas T., Wolter C., Tarkan S.A., Tricarico E., Trichkova T., Verreycken H., Witkowski A., Zhang C.G., Zweimueller I., Britton R.J. 2010b - Pan-continental invasion of Pseudorasbora parva: towards a better understanding of freshwater ?sh invasion - Fish Fish. 11: 315-340.

Grabowska J., Przybylski M. 2015 - Life-history traits of non-native freshwater fish invaders differentiate them from natives in the Central European bioregion - Rev. Fish Biol. Fish. 25: 165-178.

Grabowska J., Kotusz J., Witkowski A. 2010 - Alien invasive fish species in Polish waters: an overview - Folia Zool. 59: 73-85.

Guo Q., Olden J.D. 2014 - Spatial scaling of non-native fish richness across the United States - PLoS ONE 9(5): e97727. doi:10.1371/journal.pone.0097727.

Jackson M.C., Britton J.R. 2013 - Variation in the trophic overlap of invasive Pseudorasbora parva and sympatric cyprinid fishes - Ecol. Freshw. Fish 22: 654-657.

Kapusta A. 2004 - Impact of varied environmental conditions on the distribution and abundance of fry in the littoral zone of Lake Licheńskie - Inland Fisheries Institute, PhD thesis, Olsztyn, 139 p. (in Polish)

Kapusta A. 2011 - Ecological risks associated with exotic species introduced into aquaculture - In: New species in aquaculture - reproduction, rearing, prophylactics (Eds) Z. Zakęś, K. Demska-Zakęś, A. Kowalska, Wyd. IRS, Olsztyn: 319-324 (in Polish).

Kapusta A., Bogacka E., Czarnecki B. 2006 - Pseudorasbora parva (Schlegel, 1842) in the Konin lakes: spread of new fish species in lakes that are spatially isolated - In: Book of abstracts of the 20th Conference of Polish Hydrobiologists 5-8 September 2006, Torun (in Polish).

Kapusta A., Bogacka-Kapusta E., Czarnecki B. 2008 - The significance of stone moroko, Pseudorasbora parva (Temmick and Schlegel), in the small-sized fish assemblages in the littoral zone of the heated Lake Licheńskie Arch. Pol. Fish. 16: 49-62.

Kapusta A., Kutsokon Y., Bogacka-Kapusta E. 2014 - Comparisons of morphometrics recently established population of topmouth gudgeon (Pseudorasbora parva) from a heated lakes in Poland - Acta Universitatis Prešoviensis, Folia Oecologica 6: 4-8.

Kolman R., Kapusta A., Duda A., Wiszniewski G. 2011 Review of the current status of the Atlantic sturgeon Acipenser oxyrinchus oxyrinchus Mitchill 1815, in Poland: principles, previous experience, and results - J. Appl. Ichthyol. 27: 186-191. 
Kotusz 2011 - Carassius auratus gibelio (Bloch, 1782) - In: Alien species in the fauna of Poland (Eds) Z. Głowaciński, H. Okarma, J. Pawłowski, W. Solarz, Instytut Ochrony Przyrody PAN, Kraków: 376-381 (in Polish).

Kraszewski A., Zdanowski B. 2007 - Sinanodonta woodiana (Lea, 1834)(Mollusca)-a new mussel species in Poland: occurrence and habitat preferences in a heated lake system - Pol. J. Ecol. 55: 337-356.

Najberek K., Solarz W. 2011 - Konin Lakes as a hot-spot for biological invasion in Poland - In: Alien species in the fauna of Poland (Eds) Z. Głowaciński, H. Okarma, J. Pawłowski, W. Solarz, Instytut Ochrony Przyrody PAN, Kraków: 614-623 (in Polish).

Opuszyński K., Bieniarz K. 1974 - Present state and prospects for warm water fish reproduction and managing the first stages of growth under artificial conditions - Rocz. Nauk Rol. 96-H-3: 27-43 (in Polish).

Pikitch E.K., Doukakis P., Lauck L., Chakrabarty P., Erickson D.L. 2005 - Status, trends and management of sturgeon and paddlefish fisheries - Fish Fish. 6: 233-265.

Rahel F.J., Olden J.D. 2008 - Assessing the effects of climate change on aquatic invasive species - Conserv. Biol. 22: 521-533.

Rylková K., Kalous L., Bohlen J., Lamatsch D.K., Petrtýl M. 2013 - Phylogeny and biogeographic history of the cyprinid fish genus Carassius (Teleostei: Cyprinidae) with focus on natural and anthropogenic arrivals in Europe Aquaculture 380: 13-20.

Schlaepfer M.A., Sax D.F., Olden J.D. 2011 - The potential conservation value of non-native species - Conserv. Biol. 25: 428-437.

Sinicyna O.O., Zdanowski B. 2007 - Development of the zebra mussel, Dreissena polymorpha (Pall.), population in a heated lakes ecosystem. II. Life strategy - Arch. Pol. Fish. 15: 387-400.

Stawecki K., Zdanowski B., Pyka J.P. 2013 - Long-term changes in post-cooling water loads from power plants and thermal and oxygen conditions in stratified lakes Arch. Pol. Fish. 21: 331-342.

Szumiec J., Ronchetti A. 1987 - Black buffalo in Polish waters - Gosp. Ryb. 39: 5-7 (in Polish).

Tereshchenko V.G., Kapusta A., Wilkońska H., Strelnikova A.P. 2007 - Long-term changes in 0+ fish assemblages in the littoral zone of heated lakes. I. Diversity, evenness and dynamic phase portrait of species structure - Arch. Pol. Fish. 15: 415-430.

Wilkońska H. 1988a - The effect of heated-water discharge in the Konin lakes (Poland) on their ichthyofauna - Ekol. pol. 36: 145-163.

Wilkońska H. 1988b - Effect of the introduction of herbivorous fish in the heated Lake Gosławskie (Poland) on the fry of local ichthyofauna - Ekol. pol. 36: 275-281.

Wilkońska H. 1994 - Changes in the efficiency of natural reproduction and survival of fish larvae in heated Konin lakes - Arch. Pol. Fish. 2: 285-299.

Wilkońska H., Żuromska H. 1977a - Changes in the species composition of fry in the shallow littoral of heated lakes of the Konin lakes complex - Rocz. Nauk Rol. 97-H: 113-134 (in Polish).

Wilkońska H., Żuromska H. 1977b - Observations of fish reproduction in the Konin lakes complex heated by effluent waters from a power plant - Rocz. Nauk Rol. 97-H: 77-89 (in Polish).

Witkowski A. 2009 - On the expansion and occurrence of an invasive species - Pseudorasbora parva (Temminck et Schlegel, 1846) (Teleostei: Cyprinidae: Gobioninae) in Poland - Fragm. Faun. 52: 25-32.

Witkowski A. 2011 - Oreochromis niloticus (Linnaeus, 1757) - In: Alien species in the fauna of Poland (Eds) Z. Głowaciński, H. Okarma, J. Pawłowski, W. Solarz, Instytut Ochrony Przyrody PAN, Kraków: 421-422 (in Polish).

Witkowski A., Grabowska J. 2012 - The non-indigenous freshwater fishes of Poland: Threats to the native ichthyofauna and consequences for the fishery: A review - Acta Ichthyol. Piscat. 42: 77-87.

Záhorská E., Balážová M., Š́rová M. 2013 - Morphology, sexual dimorphism and size at maturation in topmouth gudgeon (Pseudorasbora parva) from the heated Lake Licheńskie (Poland) - Knowl. Manag. Aquat. Ecosyst. 411: 07. DOI: 10.1051/kmae/2013074.

Záhorská E., Kováč V., Švolíková K., Kapusta A. 2014 Reproductive parameters of topmouth gudgeon (Pseudorasbora parva) from a heated Lake Licheńskie (Poland) - Cent. Eur. J. Biol. 9: 212-219.

Zawisza J., Backiel T. 1972 - Some results of fishery biological investigation at heated lakes - Verh. Int. Verein. Limnol. 18: 1190-1197. 